\title{
Globicephaline whales from the Mio-Pliocene Purisima Formation of central California, USA
}

Robert W. Boessenecker, Frank A. Perry, and Jonathan H. Geisler

Acta Palaeontologica Polonica 60 (1), 2015: 113-122 doi: http://dx.doi.org/10.4202/app.2013.0019

Oceanic dolphins (Odontoceti: Delphinidae) constitute the most speciose family of extant cetaceans, yet their fossil record is limited. Although several extinct species are known from Mediterranean and North Atlantic localities, there are few examples from deposits along the Pacific Rim. Despite the rich record of successive marine mammal fossil assemblages in the extensively sampled eastern North Pacific, only one fossil delphinid, Protoglobicephala (Pliocene, Baja California), has been described. We report globicephaline remains from the Mio-Pliocene Purisima Formation of Northern California, including a partial cranium and two isolated petrosals. The skull exhibits large ridges on the premaxillae, and cannot be referred to any extant globicephaline genus. Similarly, the petrosals cannot be referred to any described delphinid genus, although they are most similar to those of Globicephala. Linear regression analyses demonstrate that promontorium length and bony nares width scale significantly within delphinidans, and provide a new method for testing referrals of isolated fossil odontocete petrosals to taxa known only by crania. Applying this method to the new globicephalines from the Purisima Formation, we find the petrosals to be too small to represent the same taxon as the skull, thus indicating the presence of two separate species. Our results demonstrate that globicephalines had achieved a worldwide distribution by the early Pliocene, suggesting diversification of the subfamily by 5 Ma.

Key words: Mammalia, Cetacea, Odontoceti, Delphinidae, Globicephalinae, Pliocene, Purisima Formation, California.

Robert Boessenecker [Robert.boessenecker@otago.ac.nz], Department of Geology, University of Otago, Dunedin, 9010, New Zealand, and University of California Museum of Paleontology, Berkeley, California, 94720, USA; Frank A. Perry [perry@cruzio.com ], Santa Cruz Museum of Natural History, Santa Cruz, California, 95062, USA; Jonathan H. Geisler [jgeisler@ nyit.edu], Department of Anatomy, New York Institute of Technology College of Osteopathic Medicine, Northern Boulevard, Old Westbury, NY, 11568, USA. 
This is an open-access article distributed under the terms of the Creative Commons

Attribution License (for details please see creativecommons.org), which permits unrestricted use, distribution, and reproduction in any medium, provided the original author and source are credited.

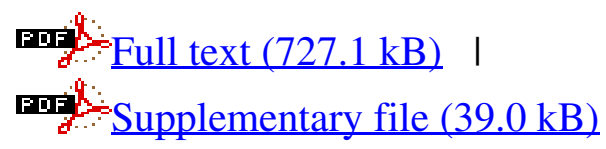

